\title{
Analysis of Business Strategies of Salesforce.com Inc.
}

\author{
Sneha M. S. ${ }^{1}$ \& Krishna Prasad K. ${ }^{2}$ \\ ${ }^{1}$ II Year MCA, College of Computer \& Information Sciences, Srinivas University, \\ Mangalore, Karnataka, India \\ ${ }^{2}$ Assistant Professor, College of Computer \& Information Sciences, Srinivas University, \\ Mangalore, Karnataka, India \\ E-Mail: mailto:mssneha748@gmail.com
}

Type of the Paper: Case Study.

Type of Review: Peer Reviewed.

Indexed In: OpenAIRE.

DOI: http://dx.doi.org/10.5281/zenodo.1252028.

Google Scholar Citation: $\underline{\text { IJCSBE }}$

\section{How to Cite this Paper:}

Sneha, M. S. \& Krishna Prasad, K. (2018). Analysis of Business Strategies of Salesforce.com Inc. International Journal of Case Studies in Business, IT and Education (IJCSBE), 2(1), 37-44. DOI: http://dx.doi.org/10.5281/zenodo.1252028.

International Journal of Case Studies in Business, IT and Education (IJCSBE)

A Refereed International Journal of Srinivas University, India.

(C) With Authors.

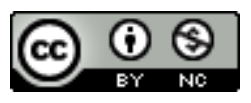

This work is licensed under a Creative Commons Attribution-Non Commercial 4.0 International License subject to proper citation to the publication source of the work.

Disclaimer: The scholarly papers as reviewed and published by the Srinivas Publications (S.P.), India are the views and opinions of their respective authors and are not the views or opinions of the S.P. The S.P. disclaims of any harm or loss caused due to the published content to any party. 


\title{
Analysis of Business Strategies of Salesforce.com Inc.
}

\author{
Sneha M. S. ${ }^{1}$ \& Krishna Prasad K. ${ }^{2}$ \\ ${ }^{1}$ II Year MCA, College of Computer \& Information Sciences, Srinivas University, \\ Mangalore, Karnataka, India. \\ ${ }^{2}$ Assistant Professor, College of Computer \& Information Sciences, Srinivas University, \\ Mangalore, Karnataka, India \\ E-Mail:mssneha748@gmail.com
}

\section{ABSTRACT}

Salesforce.com is a cloud computing company originated from SanFrancisco of America. Salesforce also enhances its business on commercial applications of social networking through achievement and internal development. Company headquarters in SanFrancisco as of early 2016, it standout among the most much esteemed American cloud computing organizations with a market capitalization above \$61 billion. In August 2017, Salesforce declared that it had come to the $\$ 10$ billion income run rate turning into the main venture cloud organization to do as such. In spite of the fact that its income originates from Customer Relationship Management (CRM), Sales drive likewise gains by business uses of long range interpersonal communication through obtaining and inner improvement. Salesforce is the world's No.1 Customer Relationship Management (CRM) system. Cloudbased applications for sales, service, marketing, and more don't require IT, experts, to set up or manage simply log in and start connecting with customers in a whole new way. Salesforce is the essential or primary venture offering inside the Sales compel Platform. It gives organizations an interface for case administration and errand administration, and a framework for naturally steering and raising imperative occasions. In this paper, we have analysed the business strategy of the company using SWOT analysis framework.

Keywords: Case Study, Salesforce, Services, Operation, Technology, Venture Capital Fund, Careers.

\section{INTRODUCTION :}

Salesforce headquartered in Francisco founded in 1999 by previous Oracle official/Executive Marc Benioff, Parker Harris, Dave Moellenhoff, and Frank Dominguez as an organization represents considerable authority in programming as an administration. Present CEO of Salesforce is Marc Benioff. Salesforce announced the development of its Customer Success Platform to entwine Sales power's administrations; it includes sales, service [1], marketing, analytics, community, and mobile apps. It is the best web-based flexible and powerful database supplier available in the market. Salesforce is known best for its CRM. Salesforce is a worldwide cloud computing company located in the united state of America. Salesforce is a cloud computing technology. It is available in the cloud, no need to install any software and no hardware required. In salesforce.com developed own applications or if we need any application we can buy it from app exchange. App Exchange is a marketplace to sell the custom applications and to buy applications from app exchange [2].

This paper contains ten sections. Section 1 explains the brief introduction of Salesforce.com. Section 2 explains objectives of the paper. Section 3 describes smart product and services of Salesforce.com; Section 4 narrates different services of Salesforce. Section 5 describes companies' services in different perspective. Section 6 explains different technologies used by the Salesforce.com. Section 7 describes social responsibilities of the concerned company. A section 8 talks about competitors of Salesforce, Section 9 explains about financials of the Salesforce, Section 10 makes SWOT analysis of Salesforce.com and Section 11 concludes the paper. 


\section{OBJECTIVES :}

- To Increase sales volume

- To analyze the overall Growth of the company.

- To find the Services and Products provided by the company.

- To find out the Market Share of the company.

\section{SMART PRODUCT \& SERVICE :}

Salesforce Applications: Salesforce includes pre-built applications (or "apps") for customer relationship management (CRM) ranging from sales force automation to partner relationship management, marketing, and customer service.

Lightning Platform: The Lightning platform is the first platform as a service (PaaS). Developers can create and deliver any kind of business application entirely on demand and without software. The platform also includes easy to use point-and-click customization tools to help you create solutions for your unique business requirements, without any programming experience.

AppExchange: AppExchange is a marketplace featuring hundreds of cloud applications created by Salesforce customers, developers, and partners. Many of the applications are free and all of them are pre-integrated with Salesforce, enabling you to easily and efficiently add functionality.

Salesforce.com Community: Salesforce provides training, support, consulting, events, best practices, and discussion boards to help you be successful.

\section{SERVICES :}

App Cloud: ForceApp Cloud.com acts as a platform as a service, which is one of the services of cloud services that enables designers to make multitenant (programming running on a server as a solitary or single occasion, serving different occupants) add-on applications that incorporate into the principle Salesforce.com application. Force.com applications are hosted on Salesforce.com's infrastructure. Force.com applications are manufactured utilizing decisive devices, sponsored by Lightning and Apex (a restrictive Java-like programming dialect for Force.com) and Lightning and Visual power (a system that incorporates an XML sentence structure regularly used to produce HTML). The Force.com stage normally gets three finish releases a year. As the stage is given as a support of its engineers, each and every improvement occurrence likewise gets all these updates [3].

Community Cloud: Community Cloud gives Salesforce clients the capacity to make online web properties for outer cooperation, client benefit, channel deals, and other custom gateways in their occasion of Sales drive. Firmly incorporated into Sales Cloud, Service Cloud, and App Cloud, Community Cloud can be immediately tweaked to give a wide assortment of web properties.

Work.com: Work.com, already Rypple, is a social execution administration stage that enables supervisors and representatives to enhance work execution through nonstop instructing, ongoing criticism, and acknowledgment.

Data.com: Beforehand known as Jigsaw, is a cloud-based automatic or controlled framework for gaining and overseeing CRM records inside a client's Salesforce.com accountData.com is likewise an online professional listing of organizations and business experts that are manufactured, kept up and gotten to or accessed by an overall group of over a million endorsers. Data.com uses a client produced database that is constantly refreshed by its individuals. Data.com's contacts go about as a virtual business card, offering name, title, postal and email addresses and direct-dial telephone numbers for singular contacts.

Desk.com: Desk.com is an assistance work area and client support item available through the cloud.

Configuration: Salesforce clients can organize their CRM function. In the framework or structure, there are tabs, for example, "Contacts", "Reports", and "Records". Every tab contains related data. Design should be likely on every tab by counting client characterized custom fields.

AppExchange: Started in 2005, the Salesforce AppExchange is an online request or application commercial center for outsider applications that keep running on the Force.com stage. Applications are accessible for free, and also by means of yearly or monthly membership models. Applications accessible range from combinations with SharePoint to versatile endorsement administration. 
Do.com: Do.com was a cloud-based task administration framework for little gatherings or a group of small members and organizations, presented in 2011 and suspended in 2014. Salesforce did not offer any explanation behind closing down the administration, anyway, it gave an Export apparatus to spare information entered inside the Do.com interface.

\section{SOLUTION :}

Salesforce.com with close to a decade of experience and many successful engagements, Info gain provides consulting, integration [5], implementation, assessment and support services. Our suite of services helps you fine-tune your existing Salesforce implementation or embark on a new journey on the Salesforce cloud. Our unified customer engagement framework helps seamlessly integrate your sales, service, marketing, custom and social clouds, delivering a unified experience to all customerfacing solutions. Our SFDC user experience and analytics capabilities deliver actionable customer insights and better-engaged customer. In today's customer-centric market, customer engagement is the key to unlocking your company's true digital potential. Businesses that are able to leverage cloud, Software-as-a-Services and Platform-as-a-Service are the ones that succeed in unlocking the true potential of customer engagement as a strategy. While there are many technology options in this space, Salesforce.com is the customer engagement platform chosen by more than 150,000 enterprises worldwide. At Info gain, our skilled and experienced professionals help you realize the true potential of your Salesforce investments [6].

\section{TECHNOLOGIES :}

Apex: Apex is an exclusive programming dialect gave by the Force.com stage to designers like Java and C\#. It is a specific, protest situated or strongly, object-oriented programming framework, following proper documentation and flower bracket structure. Apex can be utilized or used to execute modified capacities amid most procedures on the Force.com

Visual force: Visual force is the view control technology on the Force.com. It is the front end with which users interact. It is similar to HTML and most of the HTML annotations can be used in this. The page which is created by using visual force is called visual force page.

Lightning: Salesforce made open to all or public the front-end of its stage or platform, called Lightning. This segment based system is the thing that the Salesforce portable or mobile application is based on and clients are presently ready to expand on it too. Salesforce based on this structure is started in 2015 by discharging the Lightning Design System.

\section{SOCIAL RESPONSIBILITY :}

There are many ways to understand and develop socially responsible investing (SRI). What is "responsible" for each person is vastly different, and what might be "responsible" to one person might be "irresponsible" to others. That is the toughest part of investigating companies for SRI. While pure capitalism to some is the most responsible approach to business, others may see that this could harm other areas such as environmental stewardship or economic development. Others may believe too much capital invested into socially conscientious programs could hurt profits and investors. [7-8] Therefore, we will try to present as much information as we can to render the best opinion possible. Overall, socially responsible investments are more about leadership and paving the way, rather than compliance. Compliance is doing what is required, while corporate responsibility is about leading and doing more than is required [9-11]. Companies that leads are always the most respected in the long term, and we believe provide both a safe investment platform as well as peace of mind [12-16].

\section{COMPETITORS :}

- Oracle Corporation

- SAP

- Net Suite

- Yammer 
International Journal of Case Studies in Business, IT and

\section{FINANCIALS :}

The Salesforce.com Assets are shown in Table 1. Table 2 shows Annual Income Statement. Table 3 shows Long term Assets of Salesforce.com.

Table 1: Short term Assets of Saleforce.com

\begin{tabular}{|l|l|l|l|}
\hline METRIC & $\begin{array}{l}\text { VALUE (Dollars in } \\
\text { millions) }\end{array}$ & PERIOD & SOURCE \\
\hline Basic share and outstanding & 685 & $7 / 31 / 16$ & $10 \mathrm{Q}$ \\
\hline Cash and cash Equivalents & $1,115,226$ & $7 / 31 / 16$ & $10 \mathrm{Q}$ \\
\hline $\begin{array}{l}\text { Short Term Marketable } \\
\text { Securities }\end{array}$ & 59,057 & $7 / 31 / 16$ & $10 \mathrm{Q}$ \\
\hline
\end{tabular}

Table 2: Annual Income Statement of Saleforce.com

\begin{tabular}{|l|l|l|l|l|l|}
\hline Period Ending & Trend & $\mathbf{1 / 3 1 / 2 0 1 7}$ & $\mathbf{1 / 3 1 / 2 0 1 6}$ & $\mathbf{1 / 3 1 / 2 0 1 5}$ & $\mathbf{1 / 3 1 / 2 0 1 4}$ \\
\hline $\begin{array}{l}\text { Cash and cash } \\
\text { Equivalents }\end{array}$ & high & $\mathbf{\$ , 6 0 6 , 5 4 9}$ & $\mathbf{\$ 1 , 1 5 8 , 3 6 3}$ & $\mathbf{\$ 9 0 8 , 1 1 7}$ & $\mathbf{\$ 7 8 1 , 6 3 5}$ \\
\hline $\begin{array}{l}\text { Short term } \\
\text { investment }\end{array}$ & low & $\$ 602,338$ & $\$ 1,567,014$ & $\$ 87,312$ & $\$ 57,139$ \\
\hline Net Receivable & High & $\$ 3,196,643$ & $\$ 2,496,165$ & $\$ 1,905,506$ & $\$ 1,360,837$ \\
\hline $\begin{array}{l}\text { Other current } \\
\text { Assets }\end{array}$ & Medium & $\$ 591,297$ & $\$ 509,781$ & $\$ 613,609$ & $\$ 480,641$ \\
\hline $\begin{array}{l}\text { Total Current } \\
\text { Assets }\end{array}$ & High & $\$ 5,996,827$ & $\$ 5,731,323$ & $\$ 3514,544$ & $\$ 2,680,252$ \\
\hline
\end{tabular}

Table 3: Long term Assets of Salesforce.com

\begin{tabular}{|l|l|l|l|l|}
\hline $\begin{array}{l}\text { Long-term } \\
\text { Investments }\end{array}$ & $\$ 566,953$ & $\$ 520,721$ & $\$ 1,070,629$ & $\$ 482,243$ \\
\hline Fixed Assets & $\$ 1,787,534$ & $\$ 1,715,828$ & $\$ 1,125,866$ & $\$ 1,240,746$ \\
\hline Goodwill & $\$ 7,263,846$ & $\$ 3,849,937$ & $\$ 3,782,660$ & $\$ 3,500,823$ \\
\hline Intangible Assets & $\$ 1,255,045$ & $\$ 613,071$ & $\$ 433,398$ & $\$ 481,917$ \\
\hline Other Assets & $\$ 486,869$ & $\$ 142,097$ & $\$ 575,234$ & $\$ 613,490$ \\
\hline $\begin{array}{l}\text { Deferred Asset } \\
\text { Charges }\end{array}$ & $\$ 227,849$ & $\$ 189,943$ & $\$ 162,796$ & $\$ 153,459$ \\
\hline Total & $\$ 17,584,923$ & $\$ 12,762,920$ & $10,665,127$ & $\$ 9,152,930$ \\
\hline
\end{tabular}

10. SWOT Analysis :

Salesforce.com is analyzed using Strength, Weakness, Opportunity, and Challenges.

\section{Strengths}

- The barriers to market entry can be solved.

- Monetary assistance is provided in the company.

- Skilled workforces are available in the company.

- Salesforce.com reduced the labour costs through its cloud services.

- They can maintain the existing distribution and sales networks.

- The Salesforce.com provides unique products for cloud services.

- A small company can easily set up their infrastructure using Salesforce.com cloud services.

Weaknesses

- Future productivity.

- High investments in research and development.

Opportunities

- Slaesforce.com is a Growing economy.

- Growth rates and profitability. 
- Venture capital.

- Income level is at a constant increase.

\section{Threats}

- Cloud services popularity can enhance and increase.

- Price changes.

- Increase in labour costs.

- Growing competition and lower profitability.

\section{CONCLUSION :}

The record-level access controls at the heart of the Lightning Platform are extremely flexible and powerful, and serve the collaboration and security needs of all customers-from those working in small sales teams to those working in very large enterprises[17-20]. With the knowledge and features described in this paper, Salesforce developers and administrators can optimize system performance while continuing to deliver the flexibility their companies require access control [21-31]. Salesforce.com business strategies are discussed as per the guidelines are given in Company analysis case study methodology [32-36].

\section{REFERENCES :}

[1] Planning, S. (1958). Inventory Control. Lecture Notes in Economics and.

[2] http://www.btpartners.com/wp-content/uploads/2016/06/Distribution_Brochure-Cloud ERPweb1.pdf. Accessed on 22-05-2018.

[3] Weismann, C., \& Wong, S. (2010). U.S. Patent No. 7,779,039. Washington, DC: U.S. Patent and Trademark Office Cushman, M. (2010). Cloud computing and SaaS as new computes platforms. Communications of the ACM, 53(4), 27-29.

[4] Knorr, E., \& Gruman, G. (2008). What cloud computing really means. InfoWorld, 7, 20-20.

[5] Cusumano, M. (2010). Cloud computing and SaaS as new computes platforms. Communications of the ACM, 53(4), 27-29.

[6] Cinarkaya, B., Bulumulla, I. U., \& Guest, R. (2013). U.S. Patent No. 8,566,654. Washington, DC: U.S. Patent and Trademark Office.

[7] Benioff, M., \& Adler, C. (2009). Behind the Cloud: The untold story of how salesforce. com went from idea to billion-dollar company-and revolutionized an industry. John Wiley \& Sons.

[8] Barbara, B. (2010). Salesforce. com: Raising the level of networking. Inf. Today, 27, 45-45.

[9] Fisher, S., Bezar, E. D., Gross, A., Swinson, I., Hu, G., \& Oikawa, Y. (2010). U.S. Patent No. 7,774,366. Washington, DC: U.S. Patent and Trademark Office.

[10] Weissman, C., Moellenhoff, D., Wong, S., \& Nakada, P. (2014). U.S. Patent No. 8,732,157. Washington, DC: U.S. Patent and Trademark Office.

[11] Leavitt, N. (2009). Is cloud computing really ready for prime time?. Computer, 42(1).

[12] Fidel, R. (1984). The case study method: a case study. Library and Information Science Research, 6(3), 273-288.

[13] Yin, R. K. (1992). The case study method as a tool for doing evaluation. Current Sociology, 40(1), 121-137.

[14] Stake, R. E. (1978). The Case Study Method in Social Inquiry 1. Educational researcher, 7(2), 58.

[15] Stake, R. E. (1983). The case study method in social inquiry. In Evaluation models (pp. 279286). Springer Netherlands. 
[16] Flyvbjerg, B. (2006). Five misunderstandings about case-study research. Qualitative inquiry, 12(2), 219-245.

[17] Gerring, J. (2004). What is a case study and what is it good for?. American political science review, 98(02), 341-354.

[18] Runeson, P., \& Höst, M. (2009). Guidelines for conducting and reporting case study research in software engineering. Empirical software engineering, 14(2), 131.

[19] Bowen, G. A. (2009). Document analysis as a qualitative research method. Qualitative research journal, 9(2), 27-40.

[20] Noor, K. B. M. (2008). Case study: A strategic research methodology. American journal of applied sciences, 5(11), 1602-1604.

[21] Aithal, P. S. \& Acharya, R. K. (2016). Strategic Management Models \& Indian Epics,International Journal of Management Sciences and Business Research (IJMSBR), 5(4), 180-188, DOI: http://doi.org/10.5281/zenodo.161093.

[22] Aithal, P. S. (2017). An Effective Method of Developing Business Case Studies based on Company Analysis, International Journal of Engineering Research and Modern Education (IJERME), 2(1), 16-27. DOI: http://dx.doi.org/10.5281/zenodo.400579.

[23] Reshma, Aithal P. S., Shailashree V T, Sridhar Acharya, P. (2015). An Empirical study on working from home - A popular E-business model, International Journal of Advance and Innovative Research, 2(2), 12-18. DOI : http://doi.org/10.5281/zenodo.164429.

[24] Aithal, P. S., \& Suresh Kumar, P. M. (2016). Theory A for Optimizing Human Productivity, IRA International Journal of Management \& Social Sciences, 4(3), 526-535. DOI: http://dx.doi.org/10.21013/jmss.v4.n3.p2.

[25] Reshma, Aithal, P. S \& Sridhar Acharya, P. (2015). Relevance of On-line Office Administration through Working from Home in Future Education System. International Journal of Application or Innovation in Engineering \& Management, 4(4), 44 - $53 . \quad$ DOI: http://doi.org/10.5281/zenodo.163882.

[26] Padmanabha Shenoy, and Aithal P. S., (2016). A Study on History of Paper and possible Paper Free World. International Journal of Management, IT and Engineering (IJMIE), 6(1), 337-355. DOI: http://doi.org./105281/zenodo.161141.

[27] Aithal, P.S., (2015). Comparative Study on MBA Programmes in Private \& Public Universities A case study of MBA programme plan of Srinivas University. International Journal of Management Sciences and Business Research (IJMSBR), 4(12), 106-122. DOI: http://doi.org/10.5281/zenodo.163884.

[28] Aithal P. S., and Suresh Kumar P. M., (2016). Analysis of Choice Based Credit System in Higher Education. International Journal of Engineering Research and Modern Education (IJERME), 1(1), 278-284. DOI: http://doi.org/10.5281/zenodo.161046.

[29] Varun Shenoy and Aithal, P. S. (2016). Changing Approaches in Campus Placements - A new futuristic Model. International Journal of Scientific Research and Modern Education (IJSRME), 1(1), 766 - 776. DOI : http://doi.org/10.5281/zenodo.160966.

[30] Aithal, P. S. \& Shubhrajyotsna Aithal, (2016). A New Model for Commercialization of Nanotechnology Products and Services. International Journal of Computational Research and Development, 1(1), 84-93. DOI: http://doi.org/10.5281/zenodo.163536.

[31] Shubrajyotsna Aithal \& Aithal, P. S., (2016). Student Centric Learning through Planned Hardwork - An Innovative Model. International Journal of Scientific Research and Modern Education (IJSRME), 1(1), 886-898. DOI: http://doi.org/10.5281/zenodo.61830. 
[32] Aithal, P. S. (2017). Industry Analysis - The First Step in Business Management Scholarly Research. International Journal of Case Studies in Business, IT and Education (IJCSBE), 2(1), 113. DOI: http://dx.doi.org/10.5281/zenodo.810347.

[33] Aithal, P. S. (2017). An Effective Method of Developing Business Case Studies Based on Company Analysis. International Journal of Engineering Research and Modern Education (IJERME), 2(1), 16-27. DOI: http://dx.doi.org/10.5281/zenodo.400579.

[34] Aithal, P. S., (2017). Company Analysis - The Beginning Step for Scholarly Research. International Journal of Case Studies in Business, IT and Education (IJCSBE), 1(1), 1-18. DOI: http://dx.doi.org/10.5281/zenodo.573769.

[35] Aithal, P. S., (2017). ABCD Analysis as Research Methodology in Company Case Studies. International Journal of Management, Technology, and Social Sciences (IJMTS), 2(2), 40-54. DOI: http://dx.doi.org/10.5281/zenodo.891621.

[36] Jithin Raj, K. \& Krishna Prasad, K. (2018). A Critical Study on Business Strategies of 3i Infotech Ltd. International Journal of Case Studies in Business, IT and Education (IJCSBE), 2(1), 13-21. DOI: http://dx.doi.org/10.5281/zenodo. 1247319. 